\title{
A CONSTITUCIONALIDADE DA DESAPROPRIAÇÃO JUDICIAL
}

\author{
THE CONSTITUTIONALITY OF THE JUDICIAL EXPROPRIATION
}

André André Fagundes ${ }^{1}$

RESUMO: O presente artigo ocupa-se fundamentalmente do exame da constitucionalidade do instituto da desapropriação judicial (previsto no art. 1.228, §§ 4ㅇ e 5으, do Código Civil). Para tanto, analisa algumas questões que envolveram a sua concepção e a identificação de sua natureza jurídica. Igualmente, faz análises doutrinárias e jurisprudenciais acerca da funcionalização e do regime jurídico-constitucional da propriedade. Ao final, demonstra-se a conformidade desse instrumento sustentável de regularização de núcleos urbanos informais consolidados com a ordem constitucional.

Palavras-chave: desapropriação judicial; regularização fundiária; função social da propriedade; constitucionalidade; direito à habitação.

ABSTRACT: This article is mainly concerned with the examination of the constitutionality of the judicial expropriation institute (set forth in $\S \S 4$ and 5 of Article 1228 of the Civil Code). To achieve this purpose, it analyzes some issues that involved its conception and the identification of its legal nature. Furthermore, it makes doctrinal and jurisprudential analyzes about the functionalization and legal-constitutional regime of property. At the end, it demonstrates the conformity of this sustainable instrument of regularization of consolidated informal urban settlements with the constitutional order.

Keywords: judicial expropriation; land regularization; social function of property; constitutionality; right to housing.

INTRODUÇÃO

Em razão dos grandes problemas fundiários que assolam o Brasil - onde os dados mais recentes apresentados pelo Instituto Brasileiro de Geografia e Estatística (IBGE) apontam 11,42

\footnotetext{
${ }^{1}$ Doutorando em Direito Público e Mestre em Direito Constitucional pela Universidade de Coimbra, Portugal. Especialista em Direito Processual Civil e em Direito Administrativo pelo Instituto de Direito Romeu Felipe Bacellar. Assessor do Tribunal de Justiça do Estado do Paraná. Faculdade de Direito da Universidade de Coimbra. Portugal. E-mail: andrecep@gmail.com
} 
milhões de pessoas morando nos chamados aglomerados subnormais ${ }^{2}$, o que representa $6 \%$ da população do País -, faz-se necessário uma análise sobre as possíveis soluções jurídicas para esse complexo problema urbano e social instalado.

Verifica-se que grande parte dessas áreas se deram a partir de ocupações ilegais (popularmente conhecida como invasões) de terrenos vazios, em que o proprietário, mesmo tendo acionado tempestivamente o Poder Judiciário através de uma ação petitória ou possessória, conforme o caso, e obtido a procedência do pedido, não consegue a retomada real de seu imóvel seja por falta de reforço policial, seja por impossibilidade fática decorrente da consolidação da ocupação coletiva. Tem-se, então, uma sentença de reintegração de posse infrutífera.

Por outro lado, os ocupantes - em decorrência do provimento jurisdicional - ficam eternamente impossibilitados de usucapir aquela área, até mesmo nos casos em que eles utilizam o imóvel com intuito de moradia, ou realizam obras e investimentos de caráter produtivo, com relevante caráter social e econômico, eis que a contestação da posse inviabiliza a procedência da usucapião.

Somado a isso, o poder público, antes da regularização fundiária, não pode exigir o Imposto Predial e Territorial Urbano - IPTU ou o Imposto Territorial Rural - ITR do proprietário. Com efeito, em razão da perda do domínio e dos direitos inerentes à propriedade, desaparece-se a base material do fato gerador de tais tributos, resultando na impossibilidade da subsistência da exação tributária em face do proprietário. ${ }^{3}$

Constata-se, portanto, que nos núcleos urbanos informais consolidados, além das dificuldades da Fazenda Pública para a arrecadação de tributos, proprietários e possuidores ficam sem uma solução adequada, carecendo de um tratamento especial do Estado.

Quid faciendum? A solução que se mostra mais adequada é possibilitar que os próprios possuidores indenizem o proprietário, como forma de atender os ditames da justiça social, consagrados, de um lado, no princípio da propriedade privada (arts. 5, XXII, e 170, II, CF) e, de outro, no da função social da propriedade (arts. 5ํ, XXIII, e 170, III, CF).

\footnotetext{
2 "Os aglomerados subnormais podem se enquadrar, observados os critérios de padrões de urbanização e/ou de precariedade de serviços públicos essenciais, nas seguintes categorias: invasão, loteamento irregular ou clandestino, e áreas invadidas e loteamentos irregulares e clandestinos regularizados em período recente." (Censo Demográfico 2010. Aglomerados subnormais. Informações territoriais. Disponível em: <http://biblioteca.ibge.gov.br/visualizacao/periodicos/552/cd_2010_agsn_if.pdf>. Acesso em 18 out. 2018.

${ }^{3}$ STJ - 2a Turma. AgInt no REsp 1551595/SP, Rel. Min. Humberto Martins, j. 21/06/2016, DJe 28/06/2016; STJ - 2a Turma. REsp 1144982/PR. Rel. Min. Mauro Campbell Marques, j. 13/10/2009, DJe 15/10/2009; STJ - 2a Turma. AREsp. no 337.641-SP (2013/0135648-4). Rel. Min. Benedito Gonçalves (dec. mon.), j. 13/11/2014, DJe 18/11/2014; STJ - 2a Turma. REsp 963.499/PR, Rel. Min. Herman Benjamin, j. 19/03/2009, DJe 14/12/2009; STJ - 1a Turma. REsp 1.111.364/SP, Rel. Min. Benedito Gonçalves, j. 25/08/2009, DJe 03/09/2009.
} 
A partir disso, o legislador criou a desapropriação judicial, prevista no art. 1.228, §§ 4 ํ e 5ำ, do Código Civil, como instrumento de regularização fundiária capaz de resolver um dos maiores entraves jurídicos que circundam os núcleos urbanos informais consolidados.

\section{A DESAPROPRIAÇÃO JUDICIAL}

Uma das mais expressivas mudanças realizadas pelo Código Civil de 2002 foi a criação de uma desapropriação desencadeada pelo Poder Judiciário, instituto de caráter revolucionário que não encontra paradigma no direito comparado (REALE, 2002). Para melhor aquilatar o conteúdo a ser examinado, convém transcrever o art. 1.228, §§ 4ํ e 5으, do Código Civil:

Art. 1.228. O proprietário tem a faculdade de usar, gozar e dispor da coisa, e o direito de reavê-la do poder de quem quer que injustamente a possua ou detenha. (...)

$\S 4$ O O proprietário também pode ser privado da coisa se o imóvel reivindicado consistir em extensa área, na posse ininterrupta e de boa-fé, por mais de cinco anos, de considerável número de pessoas, e estas nela houverem realizado, em conjunto ou separadamente, obras e serviços considerados pelo juiz de interesse social e econômico relevante.

$\S 5$ o No caso do parágrafo antecedente, o juiz fixará a justa indenização devida ao proprietário; pago o preço, valerá a sentença como título para o registro do imóvel em nome dos possuidores.

Tem-se aqui, em linhas gerais, que o proprietário poderá ser privado do imóvel reivindicado quando considerável número de pessoas nele realizarem obras ou serviços de relevante caráter social ou econômico. Verificando a presença dos requisitos, o juiz da causa fixará justa indenização ao proprietário; pago o preço, a sentença valerá como título para o registro do imóvel em nome dos possuidores.

A desapropriação judicial tem o fito de resolver os conflitos entre os proprietários desidiosos e possuidores que deram uma utilidade social ou econômica para o imóvel, de forma que ao invés de reaver o imóvel, diante da importância dos interesses sociais e econômicos envolvidos, o proprietário receba a justa indenização em dinheiro, tal como determina a Constituição.

Nesses casos, objetiva-se evitar a retirada de famílias que ocupam o imóvel de forma consolidada, onde a ocupação é fisicamente irreversível, mas ao mesmo tempo impedir que o proprietário suporte um sacrifício desarrazoado. Daí a necessidade de a desapropriação vir acompanhada da justa indenização (GAIO, 2007).

Discorrendo sobre o tema, Miguel REALE (2002), coordenador da reforma do Código Civil, ressalta que a lei deve conceder uma proteção especial à posse em que é exercido trabalho criador, corporificado tanto pela construção de uma residência, como a realização de investimentos 
de caráter produtivo ou cultural. Explica que não devem ser tratadas de forma igual à posse, como simples poder manifestado sobre uma coisa, como sendo atividade do proprietário, e a posse qualificada (posse-trabalho), enriquecida pela serventia do labor.

Ressalte-se que essa é uma política legislativa que visa atender à triste realidade social de quem não tem propriedade, buscando conferir um verdadeiro ônus ao proprietário desidioso, que não cumpre com a função social e econômica da propriedade (CARVALHO, 2007). Com efeito, esta previsão de incontestável interesse social - em especial para os grandes centros urbanos com áreas de notória ocupação -, além de amenizar a angústia dos sem-teto, serve como constante estímulo para que o proprietário dê à terra a sua inarredável função social (MELO, 2004).

A propósito do tema, MAZZIOTTI DI CELSO e SALERNO (2005) observam que não obstante todo instituto jurídico tenha uma função social, no sentido de que deve corresponder ao bem comum, no caso da propriedade, que é por natureza um instituto propenso à satisfação de interesses individuais e egoístas, ao estabelecer-se que esta deve cumprir sua função social, o comando constitucional sugere a legitimação de regras que sejam projetadas para mitigar a tal tendência natural em razão do interesse público.

Cumpre destacar que, embora o caráter individualista do Código Civil de 1916 tivesse sido paulatinamente diminuído pelas diversas leis que se seguiram, bem como pelo entendimento dos tribunais, a verdade é que o referido diploma ainda refletia uma sociedade agrária e eminentemente patrimonialista, razão pela qual era imprescindível a criação de institutos jurídicos específicos para a modificação de tão forte propensão legal (GOMES, 2009).

Assim, o Código Civil de 2002, seguindo os mandamentos da Constituição Federal, colocou acima da propriedade estática a propriedade dinâmica, o trabalho produtivo ao capital paralisado. Passou-se de uma visão liberal-individualista, para uma concepção social-humanista de propriedade, não mais compreendida como um direito exclusivo e absoluto (MARTINS-COSTA e BRANCO, 2002). Nesse contexto, o legislador brasileiro criou a desapropriação judicial, instituto jurídico que concretiza o princípio constitucional da função social da propriedade, conceituando a posse-trabalho, de forma a disciplinar a atividade, os direitos e os deveres do proprietário.

O novel instituto releva a preocupação da ciência jurídica com o verdadeiro direito, o da vida real. Afasta-se da torre de marfim da ciência, do estudo acadêmico indiferente à realidade, para buscar uma solução eficiente no mundo empírico ${ }^{4}$. Surgiu no ordenamento jurídico brasileiro

\footnotetext{
${ }^{4}$ Na preciosa lição de Michael SANDEL (2012), "a filosofia que não tem contato com as sobras na parede só poderá produzir uma utopia estéril."
}

Revista de Direito da Cidade, vol. 11, no 3. ISSN 2317-7721. pp.788-807 
como importantíssima ferramenta de combate ao déficit habitacional, um dos maiores problemas sociais existentes, epicentro de outros tantos problemas que afligem o país ${ }^{5}$.

Ressalte-se que a desapropriação judicial não visa excluir as demais ferramentas existentes que garantem acesso à habitação. Pelo contrário, vem a contribuir na promoção da justiça social, revelando-se um notável mecanismo sustentável de regularização fundiária. As dificuldades na obtenção de moradia adequada por populações carentes é uma realidade global com inúmeras particularidades. Sua superação, por conseguinte, reclama a adoção de diversas estratégias, com o emprego de instrumentos compatíveis com as necessidades e características locais. ${ }^{6}$

Embora não seja propriamente uma novidade o entendimento de que a despejo forçado ${ }^{7}$ de centenas de pessoas de uma ocupação irregular consolidada - sem a realização de um reassentamento adequado -, é violadora de direitos humanos e não condiz com o escopo principal buscado pelo direito, qual seja, a pacificação dos conflitos sociais, e que nesses casos o proprietário deve ser indenizado $8-9$, o instituto em exame prevê a possibilidade de os próprios possuidores, via de regra ${ }^{10}$, arcarem com a indenização. O entendimento de que cabe ao Estado indenizar o

\footnotetext{
${ }^{5}$ Hernando de SOTO (2001), um dos economistas mais importantes da atualidade, versando sobre a causa da pobreza, explica que "Third World and former communist nations do not have this representational process. As a result, most of them are undercapitalized, in the same way that a firm is undercapitalized when it issues fewer securities than its income and assets would justify. The enterprises of the poor are very much like corporations that cannot issue shares or bonds to obtain new investment and finance. Without representations, their assets are dead capital.

The poor inhabitants of these nations - the overwhelming majority - do have things, but they kack the process to represent their property and create capital. They have houses but not titles; crops but not deeds; business but not statutes of incorporation. It is unavailability of these essential representations that explains why people who have adapted every other Western invention, from the paper clip to the nuclear reactor, have not been able to produce sufficient capital to make their domestic capitalism work."

${ }^{6}$ No mesmo sentido, CASIMIRO, 2010.

${ }^{7}$ Advirta-se que embora o termo despejo seja comumente utilizado para designar a desocupação compulsória de imóvel alugado, no âmbito internacional a expressão despejo forçado é empregada para designar a situação que ora se analisa.

${ }^{8}$ Ver, nesse sentido: TJPR - 18 Câmara Cível. Apelação Cível no. 167.064-2. Rel. Des. Roberto de Vicente. j. 20/02/2008.

${ }^{9}$ Tal providência, que atende o princípio da dignidade da pessoa humana e possibilita a minimização dos danos, foi adotada pelo Conselho do Estado Francês no início do século XX, como bem relata Daniel Wunder HACHEM: "Na jurisprudência do Conselho do Estado, reclama referência o caso Couitéas (Conseil d'Etat, 30 de novembro de 1923). O senhor Couitéas havia comprado um terreno na Tunísia sobre o qual estavam instaladas tribos indígenas, e para lograr imitir-se na posse conseguiu uma decisão judicial determinando a expulsão das famílias. Na oportunidade, a Administração utilizou a sua prerrogativa de negar auxílio policial à execução de uma decisão judicial em razão do risco de perturbar a ordem pública e o interesse da coletividade. Embora a omissão traduzisse o exercício de uma prerrogativa amparada pelo ordenamento jurídico, desprovida de caráter faltoso ou culposo, o Estado foi condenado a indenizar o titular do título executivo, por ele ter suportado um sacrifício demasiadamente pesado em razão do interesse público." (HACHEM, 2013).

${ }^{10}$ Conforme aponta o Enunciado 308, aprovado na IV Jornada de Direito Civil, in verbis: "A justa indenização devida ao proprietário em caso de desapropriação judicial (art. 1.228, §5) somente deverá ser suportada pela Administração Pública no contexto das políticas públicas de reforma urbana ou agrária, em se tratando de
} 
proprietário, além de estimular invasões, tornaria a regularização fundiária insustentável. Basta considerar as dificuldades existentes em relação ao pagamento dos precatórios (GAIO, 2007).

Nessa perspectiva, a tipificação de um instituto jurídico adequado às necessidades sociais representa um grande avanço na consolidação dos princípios constitucionais da dignidade da pessoa humana (art. 1ํ, III, CF) e da função social da propriedade (art. 5ㅇ, XXIII, CF), dos objetivos fundamentais da República de solidariedade (art. 3ํ, I, CF), de desenvolvimento nacional (art. 3으, II, CF), e da erradicação da pobreza e da marginalização (art. 3ํ, III, CF), do direito de moradia (art. 6으, CF), bem como da garantia do bem-estar dos habitantes da cidade (art. 182, caput, CF).

Visando proporcionar um melhor entendimento do que seja essa inovação, podemos definir a desapropriação judicial como o ato pelo qual o juiz - declarando que considerável número de pessoas, na posse ininterrupta por mais de cinco anos, concederam relevante destinação social ou econômica à extensa área, urbana ou rural - acolhe pedido desses possuidores, em ação autônoma ou como matéria de defesa em ação possessória ou petitória, de pagamento de justa indenização ao proprietário como forma de aquisição originária do domínio.

\subsection{NATUREZA JURÍDICA}

Da análise do art. 1228, §§ 4ㅇ e 5ํ, do Código Civil, há autores que defendem ser hipótese de usucapião ${ }^{11}$. A confusão se deve à semelhança entre os requisitos exigidos pelo Código Civil e os do usucapião coletivo urbano. Este se dá quando uma coletividade de baixa renda ocupa para moradia, por cinco anos ininterruptos e sem oposição, uma área urbana com mais de duzentos e cinquenta metros quadrados, onde não for possível identificar juridicamente os terrenos individualmente ocupados, desde que os possuidores não sejam proprietários de qualquer outro imóvel12.

Os que defendem esse posicionamento argumentam que os requisitos exigidos nesse dispositivo legal para a perda da propriedade (posse ininterrupta e de boa-fé) são típicos do instituto do usucapião.

Alegam também que seria inconcebível se falar em desapropriação, pois esta é um ato administrativo, e não judicial, como previsto no art. 1.228, § 4으, Código Civil.

possuidores de baixa renda e desde que tenha havido intervenção daquela nos termos da lei processual. Não sendo os possuidores de baixa renda, aplica-se a orientação do Enunciado 84 da I Jornada de Direito Civil."

${ }^{11}$ Entre eles QUEIROZ (2004), CAMBI (2003), MALUF (2006) e CARDOSO (2004).

12 Tal como estabelece o art. 10, da Lei no 10.257/2001 - Estatuto da Cidade. 
Afirmam ainda que o pagamento da indenização prevista no § 5o do art. 1.228 configura uma espécie de usucapião oneroso, pois os possuidores usucapientes ficariam sujeitos ao pagamento de uma justa indenizaçã $0^{13}$. No entanto, o novel instituto dos parágrafos 40 e 5ㅇ do art. 1.228 do Código Civil se enquadra como espécie de desapropriação ${ }^{14-15}$, como se verá a seguir.

A despeito das já comentadas semelhanças que se notam entre o usucapião coletivo e a desapropriação judicial, cabe lembrar que para o deferimento do pedido de usucapião exige-se - em todas as espécies - a existência do binômio comportamento passivo do proprietário e comportamento ativo do possuidor (DINIZ, 2008)

Como corolário lógico da exigência de inação do proprietário para a procedência da ação de usucapião, se o imóvel for reivindicado ${ }^{17}$, torna-se incabível a aquisição da propriedade através do usucapião.

Assim, seria um desatino pensar em aquisição da propriedade pelo usucapião quando se tem presente a oposição da posse pelo proprietário.

Convém enfatizar que pela redação do $\S$ 4ำ do art. 1.228 do Código Civil, além do cumprimento dos demais requisitos, a aplicação da desapropriação judicial está restrita aos imóveis reivindicados ${ }^{18}$. Observa-se que, por uma questão lógica, se o imóvel não fosse reivindicado, bastaria os possuidores ingressarem com uma simples ação de usucapião coletiva para terem declarado em seu favor a propriedade do bem.

\footnotetext{
${ }^{13}$ Argumento utilizado por ZAVASCKI (2011).

${ }^{14}$ Nessa linha de pensamento, interessantes são as seguintes observações de Álvaro Manoel Rosindo BOURGUIGNON (2003): “... a novel previsão assume características peculiares, uma vez que não se trata de qualquer das formas de usucapião (não se exige animus domini, a sentença não é meramente declaratória, não se pauta na inércia do proprietário e só se torna perfeita mediante pagamento de justa indenização), mas de modalidade que, buscando referencial analógico, vem sendo denominada de 'nova forma de desapropriação' ou ainda 'expropriação privada', conforme a ela se refere a exposição de motivos do Código." ${ }^{15}$ Nesse sentido, o seguinte precedente: “... embora o instituto ainda seja pouco explorado pela doutrina e menos ainda analisado pela jurisprudência, parece-me correto afirmar que o legislador criou uma figura de expropriação judicial fundado na posse trabalho onde, preenchidas as disposições legais a respeito, deve o Magistrado conceder ao posseiro, mediante carta de sentença, o direito de propriedade (domínio) da área ocupada a título originário (até porque o direito decorre da posse individual que cada qual detém em relação ao todo) e sem a necessidade de escritura pública." (1a VC do Foro Regional VII - Itaquera da Comarca de São Paulo. Ação Possessória no 007.96.318877-9. Dr. Amable Lopez Soto. j. 20/08/2007).

${ }^{16}$ Tratando do assunto, Silvio RODRIGUES (2006) leciona que "para que a usucapião se consume requer-se, de um lado, atitude ativa do possuidor que exerce os poderes inerentes à propriedade; e de outro, atitude passiva do proprietário, que, com sua omissão, colabora para que determinada situação de fato se alongue no tempo". ${ }^{17}$ Requisito da desapropriação judicial previsto no $\S 4$ o do art. 1.228 do Código Civil.

${ }^{18}$ Como bem define Sílvio Luís Ferreira da ROCHA (2005), "reivindicar (rei vindicatio) é o poder atribuído ao proprietário de mover ação para obter o bem de quem o possua ou detenha injustamente. Vindicar é tirar o que é nosso da mão de quem injustamente o possui. Neste sentido, temos a rei (res, coisa) vindicatio." Assim, correto o enunciado no 310 aprovado na IV Jornada de Direito Civil promovida pelo Centro de Estudos Judiciários do Conselho da Justiça Federal: "Interpreta-se extensivamente a expressão 'imóvel reivindicado' (art. 1.228, § 4ㅇ), abrangendo pretensões tanto no juízo petitório quanto no possessório".
} 
Decorre disso que, inexistindo contestação da posse pelo proprietário, os ocupantes ficam livres do pagamento da indenização, haja vista a sua posse será sem oposição, requisito indispensável de qualquer modalidade de usucapião. Não nos parece haver razão para optar pela aquisição onerosa quando se tem preenchidos os requisitos para a aquisição gratuita. Realmente, a pergunta é inevitável: qual o sentido em trocar a aquisição gratuita por uma modalidade onerosa?

Mesmo após essa análise, para não restar dúvidas, vale argumentar que a desapropriação judicial não se confunde com o usucapião coletivo, previsto no art. 10 do Estatuto da Cidade, na medida em que aquela exige dos possuidores o pagamento da justa indenização, o que por si só bastaria para afastar a possibilidade de usucapião ${ }^{19}$.

Outro aspecto a ser considerado é que esse instituto não se trata de uma desapropriação propriamente dita, eis que não carece de lei ou decreto prévio declarando preenchidos os requisitos do art. 1.228, § 4으, do Código Civil. O emprego do termo desapropriação se justifica "pelo fato do proprietário ser privado de seu direito subjetivo mediante indenização, ao contrário da aquisição pela usucapião que não comporta qualquer tipo de compensação ao antigo titular" (FARIAS e ROSENVALD, 2014) ${ }^{20}$. Na desapropriação judicial do Código Civil há uma sentença constituindo o direito de propriedade dos possuidores - desconstituindo, consequentemente, o do antigo proprietário - que se consumará quando ocorrer o pagamento da justa indenização pelos possuidores.

Tem-se, portanto, o exercício de poderes expropriatórios pelo Poder Judiciário, em casos concretos, sem a intervenção dos demais poderes. É a interferência do Estado, por meio do desapossamento do proprietário, quando extrapola a esfera de seu direito individual (TOLEDO, 2006).

\section{A CONSTITUCIONALIDADE DO INSTITUTO}

${ }^{19}$ Cf. TARTUCE (s.d.). Por sua vez, Marco Aurélio Bezerra de MELO (2004) deixou firme que "a nova previsão legal se assemelha demais com a usucapião, mas com a mesma não se confunde. Como sabido, não existe possibilidade de usucapião sem a presença do elemento subjetivo animus domini [...] e se observarmos atentamente, constataremos que o artigo não exige o referido requisito. Se para alguns, o referido requisito já está implícito na norma quando esta exige que se tenha realizado no imóvel obras e serviços considerados pelo juiz de interesse social e econômico relevante, difícil é ultrapassar a possibilidade que a lei cria, para por fim ao conflito, de pagamento do preço."

${ }^{20}$ A propósito, Orlando GOMES (1987) aponta que a "desapropriação haverá sempre que a propriedade privada seja limitada ou agredida em tais condições que o interesse do titular como proprietário do bem cessa; quando, por outras palavras é tolhido o 'gozo standart' da coisa."

Francisco Eduardo LOUREIRO (2009), por seu turno, entende que o instituto "cuida-se de alienação compulsória do proprietário sem posse ao possuidor sem propriedade, que preencha determinados requisitos previstos pelo legislador. Inicia a regra afirmando que o proprietário também pode ser privado da coisa, criando o legislador, assim, uma nova modalidade de perda da propriedade imóvel, por sentença judicial." 
O dispositivo em comento está em constante questionamento sobre a sua constitucionalidade, sob a alegação de violar o direito de propriedade e incentivar a invasão de $\operatorname{terras}^{21}$

Sustentam que o preceito é inconstitucional, irrealizável e inconveniente sob a luz da Constituição Federal. Inconstitucional por não caber ao legislador ordinário criar uma nova modalidade de desapropriação, ainda mais sem prévia indenização; irrealizável por não ter sido definido quem pagará a indenização; e inconveniente por ficar a critério exclusivo do juiz, sem controle do Poder Executivo e, muito menos, sem a fiscalização do Poder Legislativo (PEREIRA, 1973).

Aqueles que entendem pela inconstitucionalidade da norma alegam, ainda, incompatibilidade vertical, pois partem do princípio que a Constituição, ao garantir o direito de propriedade (art. 5으, caput e inciso XXII, e art. 170, II, CF), veda qualquer tipo de intervenção nesse direito, salvo aqueles explicitamente mencionados na própria Constituição. Tais seriam, em numerus clausus, a desapropriação estatal por necessidade ou utilidade pública e interesse social, mediante justa e prévia indenização em dinheiro (art. 5ㅇ, XXIV, CF) e as modalidades de desapropriaçãosanção, derivadas do descumprimento do princípio da função social pelo proprietário (art. 182, §§ 2으, 3ํ e 4으, III, e art. 184, CF). O poder constituinte não teria contemplado outras modalidades de desapropriação (BOURGUIGNON, 2003). Sendo assim, não caberia ao legislador ordinário prever hipótese não admitida pela Constituição Federal.

Para melhor esclarecimento da problemática, devemos, primeiramente, lembrar - como dito no capítulo anterior -, que não estamos diante de uma desapropriação tradicional, em que o Estado expropriante é o próprio beneficiário da medida. Aqui o termo desapropriação 22 é empregado para demonstrar que se trata de uma atuação estatal que culmina com a privação compulsória da propriedade, independentemente da participação volitiva do antigo proprietário - que ficará limitada, como acontece nas desapropriações tradicionais (art. 5ํ, XXIV, CF), à discussão do valor da justa indenização.

\footnotetext{
${ }^{21}$ Carlos Alberto Dabus MALUF (2006) entende que "as regras contidas nos §§ 4ㅇ e 5o abalam o direito de propriedade, incentivando a invasão de glebas urbanas e rurais, criando uma forma nova de perda do direito de propriedade, mediante arbitramento judicial de uma indenização, sem sempre justa e resolvida a tempo, impondo dano ao proprietário que pagou impostos que incidam sobre a gleba."

22 Arnaldo RIZZARDO (2013) oferece oportuna anotação: “O termo 'desapropriação' envolve o sentido inverso de 'apropriação': termo este que encerra a ideia fundamental de 'tornar próprio', ou incorporar, agregar, adquirir. 'Desapropriação' é antônimo daquele, e, pois, contém a ideia oposta no significado de perda, desincorporação, desagregação, afastamento, privação do que é próprio. O significado imposto pelo prefixo 'des', de origem latina, à palavra 'apropriação', o que também ocorre com o prefixo 'ex', quando forma a palavra 'expropriação', preferida no direito francês (expropriation), no direito espanhol (expropiación) e no direito italiano (espropriazione)."
} 
E diz-se judicial, pois é uma desapropriação desencadeada pelo Poder Judiciário, o que não configura eiva de inconstitucionalidade, na medida em que o poder expropriatório não deve ser considerado prerrogativa exclusiva dos Poderes Executivo ou Legislativo. Não há razão plausível para impedir que o Poder Judiciário, diante de casos concretos de relevante interesse social, determine a perda da propriedade que não cumpria com sua função social, com o pagamento da justa indenização (REALE, 2002).

Pelo contrário, o legislador democrático andou bem ao exercer sua liberdade de conformação $0^{23}$ ao criar o instituto da desapropriação judicial como instrumento jurídico de concretização da função social da propriedade e atribuir ao Poder Judiciário a competência para aplicá-lo, porquanto os juízes estão mais próximos, em contato direto com o conflito.

É evidente que o mecanismo em estudo não configura o fenômeno do ativismo judicial ${ }^{24}$, eis que o Poder Judiciário estará simplesmente desempenhando sua função jurisdicional ao dirimir uma controvérsia, com o fim de fazer valer um direito legalmente previsto ${ }^{25}$, tal como trivialmente ocorre nas ações de usucapião, em que o juiz declara a perda da propriedade, sem que isto configure uma afronta ao princípio da separação dos poderes ${ }^{26-27}$ ou mesmo um abalo ao direito de propriedade.

É de se anotar também que a desapropriação judicial prevista no Código Civil não é realizada pelos jurisdicionados - o que romperia com o monopólio do poder de imperium pelos entes estatais - mas pelo Estado-Juiz (BOURGUIGNON, 2003).

Ademais, deve-se atentar que o inciso XXIV do art. 5 da Constituição Federal indica que a lei estabelecerá o procedimento para desapropriação por necessidade ou utilidade pública, ou por interesse social, sem limitação da competência do ente expropriante.

E para o deferimento da desapropriação judicial, nos termos do parágrafo 4으 do art. 1.228, do Código Civil, é imprescindível que o juiz vislumbre no caso concreto, além dos demais requisitos legais, o relevante interesse social. Deste modo, não se pode deixar de concluir que o estatuto civil

\footnotetext{
23 Sobre o tema, ver CANOTILHO, 2003, p. 1150-1151.

${ }^{24}$ Ver, a esse respeito, URBANO, 2014. p. 95-97.

${ }^{25}$ No mesmo sentido, ZAVASCKI (2011).

${ }^{26}$ Comentando a teoria da separação de poderes, CANOTILHO (2003) registra que "foi demonstrado por Eisenmann que esta teoria nunca existiu em Montesquieu: por um lado, reconhecia-se ao executivo o direito de interferir no legislativo porque o rei gozava do direito de veto; em segundo lugar, porque o legislativo exerce vigilância sobre o executivo na medida em que controla as leis que votou, podendo exigir aos ministros conta da sua administração; finalmente o legislativo interfere sobre o judicial quando se trata de julgar os nobres pela Câmara dos Pares, na concessão de amnistias e nos processos políticos que deviam ser apreciados pela Câmara Alta sob acusação da Câmara Baixa.", de modo que "verdadeiramente se tratava era de combinação de poderes."

27 Vale destacar que o mecanismo organizacional de separação de poderes se justifica pela afirmação dos direitos fundamentais (JUSTEN FILHO, 2014).
} 
encontra referência expressa na própria Magna Carta, que autoriza a desapropriação por interesse social, mediante pagamento de justa e prévia indenização (art. 5ㅇ, XXIV, CF) (BOURGUIGNON, 2003).

Com efeito, conquanto o art. 22, inciso II, da Constituição estabeleça competência privativa da União para legislar sobre desapropriação, não se exige que a matéria tenha que ser tratada em uma lei geral de desapropriações, fato este que confere constitucionalidade formal ao dispositivo em análise (GAIO, 2007).

Importa mencionar que o constituinte deixou reservado ao legislador ordinário ${ }^{28}$ um espaço para construir o que entenda por interesse social, ainda que o beneficiado não seja o poder público ou os serviços estatais (FARIAS e ROSENVALD, 2014). Mesmo na desapropriação por interesse social - regida pela Lei № 4.132/1962 -, o requisito interesse social pode cumprir-se de diversos modos e não há nenhuma exigência que o bem expropriado passe a ser de titularidade pública ${ }^{29}$. Ou seja, é possível a decretação da desapropriação por interesse social ainda que não seja por uma necessidade do Estado em si, para um serviço estatal, mas sempre que necessária ao bemestar, à vida social (CRETELLA JÚNIOR, 1992).

Efetivamente, a desapropriação não está atada apenas ao interesse da administração, mas em favor das necessidades da ordem social (FARIAS e ROSENVALD, 2014). O interesse social, portanto, é aquele que verdadeiramente permite ao Poder Público buscar o sentido social da propriedade, proporcionando a melhor distribuição e fruição da propriedade privada. Como dito, os bens expropriados por interesse social não se destinam propriamente aos órgãos da Administração, mas à coletividade (VENOSA, 2003). ${ }^{30}$ Comentando sobre o tema, José CRETELLA JÚNIOR (1972) destaca que o interesse social ocorre:

quando a expropriação se destina a solucionar os chamados problemas sociais, isto é, aqueles diretamente atinentes às classes pobres, aos trabalhadores e à massa do povo em geral pela melhoria nas condições de vida, pela mais equitativa distribuição da riqueza, enfim, pela atenuação das desigualdades sociais; quando as circunstâncias impõem a distribuição da propriedade para melhor aproveitamento ou maior produtividade em benefício da comunidade.

Denota-se, portanto, que o fato da desapropriação judicial se dar em benefício de quem exerce a posse-trabalho sobre o imóvel, não inquina de inconstitucionalidade a notável criação

\footnotetext{
${ }^{28}$ A propósito, Già Carlo ESPOSITO (2007) destaca que compete a lei disciplinar "fin dove, fin quando ed in quali limiti vi debba essere $e$ in che modo debba esistere la proprietà privata". Norberto BOBBIO (1999), registra, também, que "uma Constituição, mesmo quando perfeita, tem a função de estabelecer as regras do jogo. Não pode e não deve estabelecer como se deve jogar. Se o fizesse, não seria mais uma Constituição democrática."

${ }^{29}$ Ver, a esse respeito, BALAGUER CALLEJÓN, 2005. p. 241.

30 Como bem sintetiza Celso Antônio Bandeira de MELLO (2009), "o necessário é que a desapropriação seja feita em favor de um interesse público."
} 
legislativa em exame. O legislador encontrou uma alternativa, no mínimo, sensata ${ }^{31}$, para resolver um dos maiores entraves jurídicos que circundam as ocupações irregulares consolidadas, e que acarreta sucessivos impactos sociais ${ }^{32}$ e financeiros ${ }^{33}$ positivos.

Mas isso não significa, evidentemente, que o proprietário simplesmente perderá o seu imóvel. Absolutamente. Tal como ocorre nas desapropriações tradicionais - em que reconhecidamente não há eiva de inconstitucionalidade -, a perda da propriedade via desapropriação judicial é compensada pela justa indenização. Não há, pois, a negação do direito de propriedade; o que se nega é a admissão da ação reivindicatória. É a prevalência de uma situação humana, de caráter coletivo - inserida no âmbito da dignidade da pessoa humana, exigente de solidariedade social (art. 3으, I, CF) -, em detrimento de uma pretensão de caráter patrimonial (ALVIM NETTO, 2009), restando preservado, ainda, o núcleo essencial do direito fundamental de propriedade, porquanto a transferência do domínio é condicionada ao pagamento da indenização.

Vale lembrar que o ordenamento jurídico brasileiro vigente não concebeu nenhum direito intocável, e o direito de propriedade não é exceção ${ }^{34}$. É incontrastável que a fruição do próprio direito não é mais considerada sem limites. A concepção privatista da propriedade "tem levado, frequentemente, autores e tribunais à desconsideração da verdadeira natureza constitucional da propriedade, que é sempre um direito-meio e não um direito-fim. A propriedade não é garantida em si mesma, mas como instrumento de proteção de valores fundamentais" (COMPARATO, 1997). Observe-se que a propriedade e sua função social, além de estar prevista entre os direitos e deveres individuais (art. 5o, incisos XXII e XIII, CF), está inscrita como princípios da ordem econômica (art.

\footnotetext{
${ }^{31}$ Na preciosa lição de Muhammad YUNUS, economista, fundador do Banco Grameen e ganhador do Prêmio Nobel da Paz em 2006: "precisamos reconhecer os envolvidos - os mais pobres - não como parte do problema, mas como parte da solução" (SPIEGEL, 2010).

32 A propósito do tema, Hernando de SOTO (2001) adverte que "[the] most of the poor already possess the assets they need to make a success of capitalism. Even in the poorest countries the poor save. [...] But they hold these resources in defective forms: houses built on land whose ownership rights are not adequately recorded [...] Because the rights to these possessions are not adequately documented, these assets cannot readily be turned into capital, cannot be trated outside of narrow local circles where people know and trust each other, cannot be used as collateral for a loan an cannot be used as a share against an investment."

${ }^{33}$ Basta lembrar, por exemplo, que antes da regularização fundiária, o Município não pode exigir o Imposto Predial e Territorial Urbano - IPTU. Ver, a esse respeito, as seguintes decisões: STJ - AREsp no 337.641 - SP (2013/0135648-4). Min. Benedito Gonçalves, (dec. mon.), j. 13/11/2014, DJe: 18/11/2014; STJ - Resp no 1.111.364 - SP (2008/0126396-7). 1a Turma. Min. Benedito Gonçalves, j. 25/08/2009, DJ: 03/09/2009; TJPR Al no 1.249.353-9. 1a CC. Rel. Dr. Fábio André Santos Muniz, j. 04/11/2014, DJ: 18/11/2014.

${ }^{34}$ Tratando dos direitos e liberdades fundamentais, Francisco BALAGUER CALLEJÓN (2005) assinala que "tales posiciones subjetivas dimanantes de un orden axiológico que inspira su reconocimiento y proteción se insertan en el ordenamiento jurídico; y el ordenamiento jurídico, que es uno, completo y ha de resultar coerente, despliega sus efectos anudando a ellos unas determinadas consecuencias favorables a su eficacia y plenitud. Pero en tanto que ha de hacerlo, por un lado, respecto a todas las personas o ciudadanos, según los casos, em condiciones de igualdad, y en tanto que, por outro, es precisa también la protección de otros bienes constitucionales, forzoso es concluir que ningún derecho fundamental puede tenerse por ilimitado."
} 
170, incisos II e III, CF), reforçando o entendimento de que não se trata de puro direito individual, notadamente porque os princípios da ordem econômica são preordenados segundo a realização de seu fim: assegurar a todos existência digna, conforme os ditames da justiça social (SILVA, 2005).

O exercício da propriedade, evidentemente, deve se dar em benefício da pessoa, mas sempre observados os "fins ético-sociais da comunidade a que o seu titular pertence. Não há, em suma, direitos individuais absolutos, uma vez que o direito de um acaba onde o de outrem começa" (REALE, 2003). Nesta perspectiva, a ideia de função social está relacionada à consonância de interesses do indivíduo com os interesses da coletividade. Busca-se a harmonização desses interesses, preservando-se as prerrogativas do proprietário enquanto o bem "detenha sua capacidade de multiplicação da riqueza e consequente utilidade coletiva" (GUEDES, 2003).

Como dito, o direito de propriedade, como qualquer outro direito fundamental, pode ser limitado, afetado desvantajosamente. As limitações ${ }^{35}$ ao direito de propriedade são impostas por inúmeras leis, tais como o Estatuto da Cidade, a Lei de Proteção ao Meio Ambiente, o Código Florestal, o Estatuto da Terra, Lei de Locações e o Código de Mineração, que podem ser de natureza administrativa, eleitoral, militar etc. ${ }^{36}$, e a Constituição Federal de 1988 dificilmente poderia ser mais explícita ao determinar, no inciso XXIII do art. 5ํ, que "a propriedade atenderá a sua função social". Mais do que uma limitação ao direito de propriedade, a função social da propriedade é hodiernamente compreendida como elemento interno ${ }^{37}$ e estrutural. Vale dizer, a função social da propriedade tornou-se parte do conteúdo essencial do direito de propriedade (BALAGUER CALLEJÓN, 2005) $)^{38}$. Condiciona a necessidade e o interesse do proprietário, com as demandas e interesses sociais da coletividade (SAULE JÚNIOR, 2004).

Na mesma linha, MAZZIOTTI DI CELSO e SALERNO (2005) registram que "la proprietà privata ha dunque una funzione sociale, cioè, se correttamente disciplinata, è elemento della struttura sociale preconizzata dalla Costituzione; deve inoltre non essere il privilagio di pochi, ma

\footnotetext{
${ }^{35}$ Na lição de José Afonso da SILVA (2005), as limitações constituem gênero - entendida como "tudo que afete qualquer dos caracteres do direito de propriedade, o que pode verifica-se com fundamento no Direito Privado ou no Direito Público" -, que podem ser restrições, servidões e desapropriação.

${ }^{36}$ No mesmo sentido, GONÇALVES, 2011, p. 245.

37 Vieira de ANDRADE (2012), por sua vez, entende que os deveres fundamentais, inclusive aqueles aparentemente associados a direitos, constituem, na maioria dos casos, uma realidade autônoma e exterior ao direito subjetivo. No entanto, o mencionado autor chega ao mesmo resultado, ao afirmar que porquanto os deveres fundamentais são explicitações de valores comunitários, tais deveres podem fundamentar a limitação dos direitos fundamentais em geral, interferindo diretamente na determinação do seu conteúdo.

38 No mesmo diapasão, COMPARATO (1997). José Afonso da SILVA (2005), por sua vez, valendo-se da lição de Pedro Escribano COLLADO, afirma que a função social da propriedade "constitui um princípio ordenador da propriedade privada e fundamento de atribuição desse direito, de seu reconhecimento e de sua garantia mesma, incidindo sobre seu próprio conteúdo".
} 
essere accesibile a tutti, il che presuppone che l'essere proprietario non sia un vuoto titolo, ma un bene sostanziale che secondo la Costituzione tutti debbono poter conseguire."

Assim, o Código Civil de 2002, trilhando o caminho demarcado pela Constituição Federal, vinculou o exercício do direito de propriedade às suas finalidades econômicas e sociais ${ }^{39}$. Tem-se, pois, que "o largo alcance da função social não é congruente com o deferimento de proteção possessória ao titular do domínio cuja propriedade não cumpra integralmente sua função social" $\left(\right.$ FACHIN, 2007) ${ }^{40}$. Com efeito, o descumprimento desse dever social constituiu uma lesão ao direito fundamental de acesso à propriedade, reconhecido doravante pela ordem constitucional. Em razão disso, o proprietário perde as garantias, judiciais e extrajudiciais, de proteção possessória, inerentes à propriedade (COMPARATO, 1997).

Diga-se mais: em caso de descumprimento dessa exigência - que, repita-se, encontra assento constitucional -, o particular poderá inclusive ser desapropriado em razão do interesse social ${ }^{41}$. De fato, "Ia consagración constitucional del principio de que la función social puede no sólo modular las facultades del propietario sobre sus bienes, sino que, cumpliénsose determinadas garantías, puede incluso determinar la expropiación misma de la cosa" (BALAGUER CALLEJÓN, 2005). Nota-se, então, que a norma tem amparo constitucional e resolve a aparente antinomia entre o direito de reivindicar a coisa de quem injustamente a possua e a função social da

\footnotetext{
${ }^{39}$ Note-se que o § $\cong 1$ do art. 1.228 emprega o termo deve, senão vejamos:

Art. 1.228. "O proprietário tem a faculdade de usar, gozar e dispor da coisa, e o direito de reavê-la do poder de quem quer que injustamente a possua ou detenha."

$\S$ 1ㅇ. "O direito de propriedade deve ser exercido em consonância com as suas finalidades econômicas e sociais e de modo que sejam preservados, de conformidade com o estabelecido em lei especial, a flora, a fauna, as belezas naturais, o equilíbrio ecológico e o patrimônio histórico e artístico, bem como evitada a poluição do ar e das águas."

${ }^{40}$ Discorrendo sobre o tema, Fredie DIDIER JÚNIOR (2009) afirma corretamente que "ao possuidor, cuja posse não esteja em conformidade com os deveres que Ihe são constitucionalmente impostos, não é deferida a tutela processual da posse. A justificativa é elementar: se a tutela da posse serve à tutela do titular do domínio, se esse domínio não é digno de proteção jurídica, porquanto em desacordo com o 'modelo constitucional do direito de propriedade', não poderá receber proteção o instrumento de realização desse mesmo direito: a posse. Fala-se, então, em uma função social da posse."

${ }^{41} \mathrm{Em}$ vetusto precedente sobre o tema, o Supremo Tribunal Federal admitiu que "O direito de propriedade não se reveste de caráter absoluto, eis que, sobre ele, pesa grave hipoteca social, a significar que, descumprida a função social que lhe é inerente (CF, art. 5o, XXIII), legitimar-se-á a intervenção estatal na esfera dominial privada, observados, contudo, para esse efeito, os limites, as formas e os procedimentos fixados na própria CR. O acesso à terra, a solução dos conflitos sociais, o aproveitamento racional e adequado do imóvel rural, a utilização apropriada dos recursos naturais disponíveis e a preservação do meio ambiente constituem elementos de realização da função social da propriedade." (ADI 2.213-MC, Rel. Min. Celso de Mello, j. 4-42002, Plenário, DJ de 23-4-2004.) No mesmo sentido: MS 25.284, Rel. Min. Marco Aurélio, j. 17-6-2010, Plenário, DJE de 13-8-2010.
} 
propriedade, com a manutenção daqueles que exerceram a posse-trabalho sobre o imóvel (NERY JUNIOR e ANDRADE NERY, 2008), mediante pagamento da justa indenização ${ }^{42}$.

Demonstrada, pois, a conformidade constitucional da perda da propriedade privada em razão do interesse social, cabe-nos ainda examinar o requisito da prévia e justa indenização em dinheiro.

Para o correto exame da questão, deve-se atentar primeiramente que a hipótese de cabimento da desapropriação judicial é justamente quando o proprietário já se encontra desapossado, de modo que não há como o pagamento da indenização ser anterior ao momento da ocupação. Além disso, como acertadamente decidiu o e. Superior Tribunal de Justiça, "a justa e prévia indenização, prevista no art. 5ํ, XXIV, da Constituição da República, está atendida quando se efetivar antes do mandado translativo do domínio"43. Considerando que, nos termos do $\S$ 5o do art. 1.228, do Código Civil, o registro da sentença só se dará após o pagamento do preço, resta afastada a alegação de inconstitucionalidade.

De mais a mais, vale lembrar que mesmo nas desapropriações tradicionais (necessidade pública, utilidade pública e interesse social), quando há discordância em relação ao valor da indenização e urgência do Poder Público de se imitir na posse, o pagamento integral só se dará quando for apurado o valor real do bem desapropriado ${ }^{44}$. Isso para não se falar no instituto da desapropriação indireta.

É de todo oportuno anotar que, embora pouco utilizada, a desapropriação judicial é mecanismo eficaz de regularização fundiária sustentável, inclusive envolvendo possuidores de baixa

\footnotetext{
42 Nessa esteira de entendimentos, Paula Ambrozim Corrêa de ARAÚJO (s.d.) anota que "a fixação de justa indenização afasta, desde logo, qualquer alegação de inconstitucionalidade da norma. Não suficiente, na aparente antinomia entre a função social da propriedade e o direito a esta, a utilização abusiva há de ser afastada, em prestígio ao próprio alcance do uso da propriedade perseguido pelo legislador constitucional. Com a comunhão dos dois elementos (pagamento + interesse social), vê-se que o instituto está socorrido pelo art. 5ํ, XXIV, da nossa Carta Magna, que permite a desapropriação por interesse social, mediante pagamento justo."

${ }^{43}$ STJ - REsp 1234606/MG, Rel. Min. Herman Benjamin, 2a Turma, j. 26/04/2011, DJe 04/05/2011.

${ }^{44}$ No mesmo sentido, GAIO, Daniel. Op. cit., p. 2182, e os inúmeros precedentes do e. STJ: AgRg no Ag 1371208/MG, Rel. Min. Humberto Martins, 2a Turma, j. 22/03/2011, DJe 04/04/2011; REsp 1185073/SP, Rel. Min. Mauro Campbell Marques, 2a Turma, j. 21/10/2010, DJe 05/11/2010; REsp 1139701/SP, Rel. Min. LUIZ FUX, 1a Turma, j. 02/03/2010, DJe 30/03/2010; REsp 692519/ES, Rel. Min. Castro Meira, 2a Turma, j. 15/08/2006, DJe 25/08/2006; MC 24740/SC (dec. mon.), Rel. Min. Napoleão Nunes Maia Filho, j. 18/09/2015, DJe 25/09/2015; REsp 1513043/MG (dec. mon.), Rel. Min. Sérgio Kukina, j. 02/06/2015, DJe 07/08/2015; AREsp 665698/MG (dec. mon.), Rel. Min. Assusete Magalhães, j. 12/03/2015, DJe 31/03/2015; MC 23887/SC (dec. mon.), Rel. Min. Og Fernandes, j. 19/02/2015, DJe 24/02/2015; REsp 1309019/SP (dec. mon.), Rel. Min. Benedito Gonçalves, j. 22/10/2014, DJe 23/10/2014.
} 
renda. A prática demonstra ${ }^{45}$ que o argumento de que os possuidores das ocupações irregulares não teriam condições de arcar com a indenização se trata de mera falácia ${ }^{46}$.

Por conseguinte, nos parece válido o Enunciado no 82, aprovado na I Jornada de Direito Civil, promovida pelo Centro de Estudos Judiciários do Conselho da Justiça Federal, sob a coordenação científica do Min. Ruy Rosado de Aguiar Júnior: "É constitucional a modalidade aquisitiva de propriedade imóvel prevista nos $\S \S ~ 4$ e 5 do art. 1.228 do novo Código Civil".

\section{CONCLUSÃO}

Com base no estudo realizado, é possível afirmar que o instituto criado no art. 1.228, §§ 4으 e 5o, do Código Civil é uma modalidade de desapropriação por interesse social, que se dá em favor quem exerce a posse-trabalho, com a contrapartida de o proprietário desidioso receber a justa indenização.

Constata-se que a criação desse mecanismo jurídico representa um grande avanço na consolidação dos princípios constitucionais da dignidade da pessoa humana, da função social da propriedade, dos objetivos fundamentais da República de solidariedade, do desenvolvimento nacional, da erradicação da pobreza e da marginalização, do direito de moradia e da garantia do bem-estar dos habitantes da cidade.

Depreende-se, também, que a desapropriação judicial poderá ser decretada pelo juiz quando, no caso concreto, sopesando as obras ou serviços realizados no imóvel reivindicado, considere-as de relevante interesse social, com a fixação da justa indenização ao proprietário destituído, a ser paga, via de regra, pelos próprios possuidores beneficiados com a medida. Desta maneira, restam atendidas as exigências para a desapropriação por interesse social do art. 5o, inciso XXIV, da Constituição Federal.

\footnotetext{
${ }^{45}$ A título exemplificativo, citamos as seguintes decisões: 1a VC do Foro Regional VII - Itaquera da Comarca de São Paulo. Ação Possessória no 007.03.024808-2. Dr. Amable Lopez Soto. j. 20/08/2007; 1a VC do Foro Regional VII - Itaquera da Comarca de São Paulo. Ação Possessória no 007.96.318877-9. Dr. Amable Lopez Soto. j. 28/08/2009; 2a VJ de Ferraz Vasconcelos. Ação Possessória no 801/2007. Dr. Marcio Ferraz Nunes, j. 12/01/2011; 3a VC do Foro Regional IV - Lapa da Comarca de São Paulo, Ação de Reintegração de Posse no 0026283-20.2001.8.26.0004. Dr. Sidney Tadeu Cardeal Banti, j. 23/08/2012;

${ }^{46}$ Muhammad YUNUS, banqueiro mencionado na nota de rodapé no 64, "fez uma constatação muitíssimo surpreendente que, ao longo dos anos, ele sempre via empiricamente confirmada: quanto menos garantias alguém tivesse para apresentar, maiores seriam a certeza e a pontualidade da restituição do crédito." (SPIEGEL, 2010), valendo mencionar que dentre os 6,6 milhões de tomadores de empréstimo, "o Banco Grameen alcança um índice de restituição de mais de noventa e nove por cento, superando, assim, de logo, todos os bancos comerciais" (Ibidem).
} 
Com base no exposto, verifica-se que a desapropriação judicial está em consonância com a ordem constitucional e, embora pouco analisada pelos Tribunais, é perfeitamente viável para solucionar os conflitos fundiários entre proprietários e possuidores em ocupações irregulares consolidadas.

\section{REFERÊNCIAS}

ALVIM NETTO, José Manoel de. Livro Introdutório ao Direito das Coisas e o Direito Civil. ALVIM, Thereza Celina Diniz de Arruda; CLÁPIS, Alexandre Laizo (Coords.). Comentários ao Código Civil Brasileiro. Rio de Janeiro: Forense, 2009, v. 11, t. I

ANDRADE, José Carlos Vieira de. Os Direitos Fundamentais na Constituição Portuguesa de 1976. 5. ed. Coimbra: Almedina, 2012.

ARAÚJO, Paula Ambrozim Corrêa de. Breves Comentários à Desapropriação Judicial (§§ 4ำ e 5ํㅡ, do art. 1.228, Código Civil/2002). Disponível em: <http://www.egov.ufsc.br/portal/sites/default/files/anexos/8912-8911-1-PB.pdf>. Acesso em: 18 out. 2018.

ASSINI, Nicola; MANTINI, Pierluigi. Manuale di diritto urbanístico. 3. ed. Milano: Giuffrè, 2007.

BALAguer CALLEJÓN, Francisco. (Coord.) Manual de Derecho Constitucional. v. II. Derechos y libertades fundamentales deberes constitucionales y princípios rectores, institucionales y órganos constittucionales. Madrid: Tecnos, 2005.

BOBBIO, Norberto. As ideologias e o poder em crise. João Ferreira (trad.) Gilson Cesar Cardoso (Rev. téc.). 4. ed. Brasília: Universidade de Brasília, 1999.

BOURGUIGNON, Álvaro Manoel Rosindo. É constitucional a modalidade aquisitiva de propriedade imóvel prevista nos $\S \S 4$ e e 5을 do art. 1.228 do novo Código Civil. In: AGUIAR JÚNIOR, Ruy Rosado de (Org.). I Jornada de Direito Civil. Brasília: Conselho da Justiça Federal, p. 351-353, 2003.

CAMBI, Eduardo. Propriedade no novo Código Civil: aspectos inovadores. Revista Síntese de Direito Civil e Processual Civil, Porto Alegre, no 25, p. 124-141, set./out. 2003.

CANOTILHO, J. J. Gomes. Direito Constitucional e Teoria da Constituição. 7. ed. Coimbra: Almedina, 2003.

CARDOSO, Gustavo D’Acol. A função Social da Propriedade Imobiliária. São Paulo, 2004. Dissertação (Mestrado em Direito) - Pontifícia Universidade Católica de São Paulo.

CARVALHO, Francisco José. Função Social da Propriedade. São Paulo, 2007. 314 f. Dissertação (Mestrado em Função Social do Direito) - Faculdade Autônoma de Direito - FADISP.

CASIMIRO, Lígia Maria Silva Melo de. Direito à Moradia no Brasil - Política Urbana e Acesso por meio da Regularização Fundiária. Belo Horizonte: Fórum, 2010. 
Censo Demográfico 2010. Aglomerados subnormais. Informações territoriais. Disponível em: $<$ http://biblioteca.ibge.gov.br/visualizacao/periodicos/552/cd_2010_agsn_if.pdf>. Acesso em 18 out. 2018.

COMPARATO, Fábio Konder. Direitos e deveres fundamentais em matéria de propriedade. Revista CEJ, Brasília, v. 1, n. 3, p. 92-99, set./dez. 1997.

CRETELLA JÚNIOR, José. Comentários à Constituição. Rio de Janeiro: Forense, 1992.

. Tratado de direito administrativo. Rio de Janeiro: Forense, 1972. v. IX.

DI CELSO, Manlio Mazziotti; SALERNO, Giulio M. Manuale di Diritto Costituzionale. 3. ed. Padova: CEDAM, 2005.

DIDIER JÚNIOR, Fredie. A função social da propriedade e a tutela processual da posse. In:

MAZZEI, Rodrigo (Coords.). Processo e Direito Material. Salvador: JusPodivm, 2009. p. 83-94.

DINIZ, Maria Helena. Curso de Direito Civil Brasileiro. Direito das coisas. 23. ed. rev., atual. e ampl. de acordo com a reforma do CPC e com o Projeto de Lei no 276/2007. São Paulo: Saraiva, 2008. v. 4.

FACHIN, Luiz Edson. O estatuto constitucional da proteção possessória. In: FARIAS, Cristiano Chaves de (Coord.). Leituras complementares de Direito Civil. Salvador: JUSPODIVM, 2007.

FARIAS, Cristiano Chaves de; ROSENVALD, Nelson. Curso de Direito Civil. Direitos Reais. 10. ed. rev. ampl. e atual. Salvador: JusPodivm, 2014. v. 5.

GAIO, Daniel. A Aquisição da Propriedade por Interesse Social: Possibilidades e Obstáculos. In: XVI Encontro Preparatório do CONPEDI, 2007, Campos dos Goytacazes. Anais do XVI Encontro Preparatório para o Congresso Nacional do CONPEDI, p. 2177-2188, 2007.

GOMES, Orlando. Questões mais recentes de direito privado: pareceres. São Paulo: Saraiva, 1987. GOMES, Wilton Luis da Silva. Inovações no regime jurídico das desapropriações. São Paulo, 2009. 231 f. Dissertação (Mestrado em Direito do Estado) - Faculdade de Direito da Universidade de São Paulo. GONÇALVES, Carlos Roberto. Direito Civil Brasileiro. Direito das coisas. 6. ed. São Paulo: Saraiva, 2011. v. 5.

GUEDES, Jéfferson Carús. Função Social das "propriedades": da funcionalidade primitiva ao conceito atual de função social. In: ALVIM NETTO, José Manoel de; CÉSAR, Joaquim Portes de Cerqueira; ROSAS, Roberto (Coords). Aspectos controvertidos do novo código civil: escritos em homenagem ao Min. José Carlos Moreira Alves. São Paulo: Revista dos Tribunais, 2003. p. 343-360.

HACHEM, Daniel Wunder. Responsabilidade Civil do Estado por Omissão: uma proposta de releitura da teoria da faute du service. In: MARQUES NETO, Floriano de Azevedo; ALMEIDA, Fernando Dias Menezes de; NOHARA, Irene Patrícia; MARRARA, Thiago (Orgs.). Direito e Administração Pública: Estudos em homenagem a Maria Sylvia Zanella Di Pietro. São Paulo: Atlas, 2013. 
JUSTEN FILHO, Marçal. Curso de Direito Administrativo. 10. ed. rev. atual. e ampl. São Paulo: Revista dos Tribunais, 2014.

QUEIROZ, Luiz Viana. Modos de aquisição da propriedade no novo Código Civil. Disponível em: <http://www.unifacs.br/revistajuridica/arquivo/edicao_junho2004/docente/doc01.doc>. Acesso em: 18 out. 2018.

LOUREIRO, Francisco Eduardo. Artigos 1.196 a 1.510 - Coisas. In: PELUSO, Cezar (Coord.). Código Civil Comentado: Doutrina e Jurisprudência. 3. ed. rev. e atual. Barueri: Manoele, 2009.

MALUF, Carlos Alberto Dabus. Arts. 1.419 a 1.510. In: FIUZA, Ricardo (Coord.). Novo Código Civil. 5. ed. atual. São Paulo: Saraiva, 2006.

MARTINS-COSTA, Judith; BRANCO, Gerson Luiz Carlos. Diretrizes Teóricas do Novo Código Civil Brasileiro. São Paulo: Saraiva, 2002.

MAZZIOTTI DI CELSO, Manlio; SALERNO, Giulio M. Manuale di Diritto Costituzionale. 3. ed. Padova: CEDAM, 2005.

MELLO, Celso Antônio Bandeira de. Curso de Direito Administrativo. 26. ed. rev. e atual. até a EC 57/2008. São Paulo: Malheiros, 2009.

MELO, Marco Aurélio Bezerra de. Novo Código Civil Anotado. Direito das Coisas. 3. ed. Rio de Janeiro: Lumen Juris, 2004. v. 5.

NERY JUNIOR. Nelson; ANDRADE NERY, Rosa Maria de. Código Civil Comentado. São Paulo: Revista dos Tribunais, 2008.

SAULE JÚNIOR, Nelson. A proteção jurídica da moradia nos assentamentos irregulares. Porto Alegre: Sergio Antonio Fabris Editor, 2004.

PEREIRA, Caio Mário da Silva. Crítica ao anteprojeto de Código Civil. Revista Forense, Rio de Janeiro. v. 242, abr./maio/jun. 1973.

REALE, Miguel. Estudos preliminares do código civil. São Paulo: Revista dos Tribunais, 2003.

. Exposição de Motivos do Supervisor da Comissão Revisora e Elaboradora do Código Civil. Revista da EMERJ, Rio de Janeiro, parte I, p. 09-34, fev./jun. 2002.

. Visão geral do Novo Código Civil. Revista da EMERJ, Rio de Janeiro, parte I, p. 38-44, fev./jun. 2002.

RIZZARDO, Arnaldo. Direito das Coisas. 6. ed. rev. e atual. Rio de Janeiro: Forense, 2013.

ROCHA, Sílvio Luís Ferreira da. Função social da propriedade pública. São Paulo, Malheiros, 2005.

RODRIGUES, Silvio. Direito civil: direito das coisas. São Paulo: Saraiva, 2006.

SANDEL, Michael J. Justiça: o que é fazer a coisa certa. Trad. de Heloisa Matias e Maria Alice Máximo.

6. ed. Rio de Janeiro: Civilização Brasileira, 2012.

SILVA, José Afonso da. Curso de Direito Constitucional positivo. 25. ed. São Paulo: Malheiros, 2005. 
SOTO, Hernando de. The Mystery of Capital. Why capitalism triumphs in the West and fails every else. London: Black Swan, 2001.

SPIEGEL, Peter. Muhammad Yunus: O Banqueiro Dos Pobres. São Paulo: Cidade Nova, 2010.

TARTUCE, Flávio. A função social da posse e da propriedade e o direito civil constitucional. Disponível em: <http://www.flaviotartuce.adv.br/assets/uploads/artigos/Tartuce_possse.doc>. Acesso em: 18 out. 2018.

TOLEDO, Roberta Cristina Paganini. A Posse-Trabalho. São Paulo, 2006. 249 f. Dissertação (Mestrado em Direito Civil Comparado) - Pontifícia Universidade Católica de São Paulo.

URBANO, Maria Benedita. Curso de Justiça Constitucional: Evolução histórica e modelos do controlo da constitucionalidade. Coimbra: Almedina, 2014.

ZAVASCKI, Teori Albino. A tutela da posse na constituição e no novo código civil. Disponível em: <http://bdjur.stj.jus.br/jspui/bitstream/2011/6723/A_Tutela_da_Posse_na_Constitui\%C3\%A7\%C3 \%A3o.pdf>. Acesso em: 18 out. 2018.

Trabalho enviado em 23 de outubro de 2018

Aceito em 30 de setembro de 2019 